\title{
Dietary feeding of freeze-dried whole cranberry inhibits intestinal tumor development in $\mathrm{Apc}^{\mathrm{min} /+}$ mice
}

\author{
Duochen Jin ${ }^{1, *}$, Tianyu Liu ${ }^{1, *}$, Wenxiao Dong1, Yujie Zhang ${ }^{2}$, Sinan Wang ${ }^{1}$, Runxiang \\ $\mathrm{Xie}^{1}$, Bangmao Wang ${ }^{1}$ and Hailong $\mathrm{Cao}^{1}$ \\ ${ }^{1}$ Department of Gastroenterology and Hepatology, General Hospital, Tianjin Medical University, Tianjin, China \\ ${ }^{2}$ Department of Pathology, General Hospital, Tianjin Medical University, Tianjin, China \\ *These authors contributed equally to this work \\ Correspondence to: Hailong Cao, email: cao_hailong@163.com \\ Keywords: cranberry; intestinal tumor; gut barrier function; epidermal growth factor receptor; Apc ${ }^{\mathrm{min} /+} \mathrm{mouse}^{-}$
}

Received: April 11,2017 Accepted: October 11,2017 Published: October 26, 2017

Copyright: Jin et al. This is an open-access article distributed under the terms of the Creative Commons Attribution License 3.0 (CC BY 3.0), which permits unrestricted use, distribution, and reproduction in any medium, provided the original author and source are credited.

\section{ABSTRACT}

It is increasingly perceived that dietary components have been linked with the prevention of intestinal cancer. Cranberry is a rich source of phenolic constituents and non-digestible fermentable dietary fiber, which shows anti-proliferation effect in colorectal cancer cells. Herein, we investigated the efficacy of long-term cranberry diet on intestinal adenoma formation in $A p c^{\mathrm{min} /+}$ mice. $A p c^{\mathrm{min} /+}$ mice were fed a basal diet or a diet containing $20 \%(\mathrm{w} / \mathrm{w})$ freeze-dried whole cranberry powder for 12 weeks, and the number and size of tumors were recorded after sacrifice. Our results showed that cranberry strongly prevented the growth of intestinal tumors by $33.1 \%$. Decreased cell proliferation and increased apoptosis were observed in tumors of cranberry-fed mice. Cranberry diet reduced the expression profile of colonic inflammatory cytokines (IFN- $\mathrm{Y}$, IL-1 $\beta$ and TNF- $\alpha$ ) accompanied with increased levels of anti-inflammatory cytokines (IL4 and IL-10). Moreover, the number of colonic goblet cells and MUC2 production were increased, and the intestinal barrier function was also improved. In addition, cranberry diet increased caecal short chain fatty acids concentrations, and down-regulated epidermal growth factor receptor signaling pathway. These data firstly show the efficacy and associated mechanisms of cranberry diet on intestinal tumor growth in $A_{p c}$ min/+ mice, suggesting its chemopreventive potential against intestinal cancer.

\section{INTRODUCTION}

Clinical data provide an overview that colorectal cancer (CRC) has become the one of the most commonly diagnosed tumors in the overall population $[1,2]$. Dietary habits with a high intake of fruits and vegetables have represented an inverse association with the risk of developing $\mathrm{CRC}$, on account of the high content of fiber and phenolic compounds [3]. There have been interests in investigating the promising roles of vegetarian meals and their constituent phytochemicals against CRC both in vitro and in vivo. American cranberry (Vaccinium spp.) is a widely consumed berry fruit in North America due to its desirable polyphenols bioactives and berry phytonutrients. Accumulating evidence shows that daily consumption of cranberry has the potential ability to promote a healthy cardiovascular system and urinary system for its antioxidant activity [4]. Lately, there is evidence to suggest that cranberry phytochemicals have anticancer properties such as limiting prostate tumorigenesis and metastasis [5-7]. Furthermore, it has been observed that cranberry consumption in patients with prostate cancer decreased the level of serum prostate specific antigen [8] and the incidence of radiation cystitis [9]. Moreover, cranberry derived phytochemicals have been evaluated to be antineoplastic compounds in many tumor cell lines, such as in human breast cancer cells [10], lung cancer cells [11], ovarian cancer cells $[12,13]$, bladder cancer cells [14] and even esophageal adenocarcinoma cell lines $[15,16]$. In addition, 
freeze-dried cranberry powder diet has been reported to alleviate inflammatory response and lipid oxidation, which is useful to individuals with the metabolic syndrome $[17,18]$.

Interestingly, several studies have investigated the bioavailability and metabolism of cranberry constituents in the gastrointestinal tract. Cranberry remained its antioxidant activity in the gastrointestinal tract, and 49 and 57 metabolites were detected in human plasma and urine after cranberry administration, respectively $[19,20]$. The rich native A-type proanthocyanidins (PACs) of cranberry improved intestinal barrier function by stimulating goblet cells proliferation and Th2 cytokines expression [21]. Cranberry supplementation significantly attenuated colitis severity and the production of Th1 cytokines induced by dextran sodium sulfate in mice, meanwhile, gut microbiota were altered and the levels of short-chain fatty acids (SCFAs) in cecum were increased [22, 23]. Adding cranberry proanthocyanidins to elemental enteral nutrition improved and maintained luminal IgA level [24]. Furthermore, regular consumption of dietary fiber offered good protection against pathogen infection by promoting the function of the intestinal mucus barrier [25]. When it comes to complex, elusive $\mathrm{CRC}$, dietary cranberry has been implicated in a decreased formation of aberrant crypt foci induced by azoxymethane in Fisher 344 male rats [26]. Cranberry extracts played a cytotoxic role in human tumor cell lines including HT-29 through apoptosis and cell cycle arrest at G1/S phase [27]. However, to date, it remains to be determined if cranberry administration inhibits spontaneous intestinal tumorigenesis in vivo.

$A p c^{\mathrm{min} /+}$ mice carrying heritable mutant $A p c$ gene would develop multiple intestinal neoplasia that is analogous to human familial adenomatous polyposis (FAP). As a tumor suppressor gene, $A p c$ gene mutations contribute to FAP and most sporadic CRC $[28,29]$. This well-established animal model develops multiple polyps spontaneously in the gut, and has emerged to fulfil important roles in investigating malignant transformation in intestinal tumorigenesis [30, 31]. Disordered Apc protein leads to decreased $\beta$-catenin degradation concomitant with the activation of the Wnt pathway $[32,33]$. $\beta$-catenin accumulates in the nucleus and binds to transcription factor belonging to lymphoid enhancing factor (LEF-1) family, which augments the transcriptional level of target genes including cyclin D1 gene [34]. Furthermore, Apc mutations are responsible for epidermal growth factor receptors (EGFR) signaling pathway activation [35]. Feng Y et al. highlighted that the inhibition of EGFR autophosphorylation and downstream targets (Akt kinase and extracellular signal-regulated kinase $1 / 2$, etc.) would suppress cell proliferation and meanwhile induce cell apoptosis [36]. EGFR inhibition has already been proven to be involved in polyp growth reduction in the $A p c^{\mathrm{min} /+}$ mouse model of intestinal carcinogenesis [37]. In the present study, we investigated the inhibitory activity and underlying mechanisms of dietary cranberry against intestinal tumorigenesis in $A p c^{\mathrm{min} /+}$ mice, which might provide a translational approach to reduce the risk of CRC.

\section{RESULTS}

\section{Cranberry supplementation inhibited intestinal tumor development}

All mice were regularly monitored to investigate the body weight and consumption of food and water during the experiment. No significant difference was found in food consumption or body weight between the control and cranberry groups throughout the study (Figure 1A). There was no mortality throughout the treatment period in any group. Furthermore, no macroscopic alterations indicative of toxicity were observed in any organs of cranberrytreated mice, including the liver, kidney and lung.

The control mice developed an average of 19.25 intestinal tumors per mouse, which were mostly populated in the small intestine. Dietary feeding of cranberry significantly decreased the total number of intestinal polyps by $33.1 \%(19.25 \pm 4.62$ vs $12.88 \pm 2.90, p<0.01$; Supplementary Table 1, Figure 1B). More specifically, the prominent effect of cranberry on the decrease in larger polyps $(>1 \mathrm{~mm})$ of small intestine was observed in size distribution analysis ( $<1 \mathrm{~mm}, p>0.05$; $1-2 \mathrm{~mm}, p<0.05$; $>2 \mathrm{~mm}, p<0.05$; Figure 1C). Further, proximal and middle portions of small intestine showed 33.3\% $(p<0.05)$ and $57.7 \%(p<0.05)$ reduction in the numbers of polyps by cranberry, respectively (Figure 1D). However, there were no significant differences for the numbers of distal and colonic tumors between the two groups (Figure 1B and 1D). Both groups could develop adenomas with or without low-grade dysplasia at all segments of the intestine, which had no significant difference with respect to tumor stage. These data suggested the inhibitory effect of cranberry on tumor growth without any toxicity in $A p c^{\mathrm{min} /+}$ mice.

\section{Cranberry diet inhibited cell proliferation and induced apoptosis in intestinal tumors}

Cell proliferation and apoptosis have been implicated in evaluating intestinal tumor development in $A p c^{\mathrm{min} /+}$ mice. The level of proliferation was reflected by Ki-67 immunostaining of sections from middle small intestine Swiss rolls, which is used as a prognostic marker in human neoplasia. As shown in Figure 2A, intestinal tissue sections of the cranberry diet-fed $A p c^{\mathrm{min} /+}$ mice exhibited a significant decrease in the number of proliferative cells within tumors, compared with those of the basal diet-fed mice $(109.67 \pm 10.78$ vs $55.33 \pm 7.41$, $p<0.01)$. The level of apoptosis in adenomas of $A p c^{\mathrm{min} /+}$ mice was determined by TUNEL, and cranberry group had more apoptotic cells in tumors compared with mice on control diet $(6.33 \pm 0.47$ vs $16.67 \pm 1.70, p<0.01$, Figure 2B). 


\section{The expression profile of colonic inflammation mediators was regulated by cranberry}

Chronic inflammation of the intestinal mucosa has been suggested to play a crucial role in regulating immune response to initiate or promote CRC development [38]. In this experiment, we investigated the effect of cranberry supplementation on cytokine profiles in the pericarcinous tissues in colon. We observed that the mRNA expression levels of IFN- $\gamma$, IL- $1 \beta$ and TNF- $\alpha$ mRNA were significantly down-regulated, whereas IL-4 and IL-10 were remarkably increased in the colonic mucosa from cranberry diet-fed $A p c^{\min /+}$ mice compared with control without obviously affecting TGF- $\beta$ (Figure 3A and $3 \mathrm{~B})$. These data suggested that the inhibition of proinflammatory cytokines expression and the promotion of anti-inflammatory cytokines by cranberry diet might play a role in the process of inflammation during intestinal tumorigenesis in $A p \mathrm{Cin}^{\mathrm{min} /}$ mice.

\section{Cranberry feeding improved intestinal mucosal barrier function in $\mathrm{Apc}^{\mathrm{min} /+}$ mice}

Previous studies have suggested that colitis mouse models and patients with ulcerative colitis present a reduced number of goblet cells and thus a thinner mucus layer $[39,40]$. In the present study, immunostaining and RT-PCR were used to assess the distribution of tight junction protein, zona occludens 1 (ZO-1) and claudin 3 in the middle small intestine and the colon, respectively (Figure 4A and 4B; Supplementary Figure 1) [41]. Control group was associated with a leaky tight junction, meanwhile, cranberry supplementation restored impaired epithelial tight junction [42]. Cranberry-fed group showed higher gene expression levels of ZO-1 and claudin 3 than control group in the small intestine $(p<0.01, p<0.05$; Figure $4 \mathrm{~A}$ and $4 \mathrm{~B}$ ). PAS staining showed that diet supplementation with cranberry increased the number of goblet cells compared with control diet $(22.35 \pm 4.46 v s$
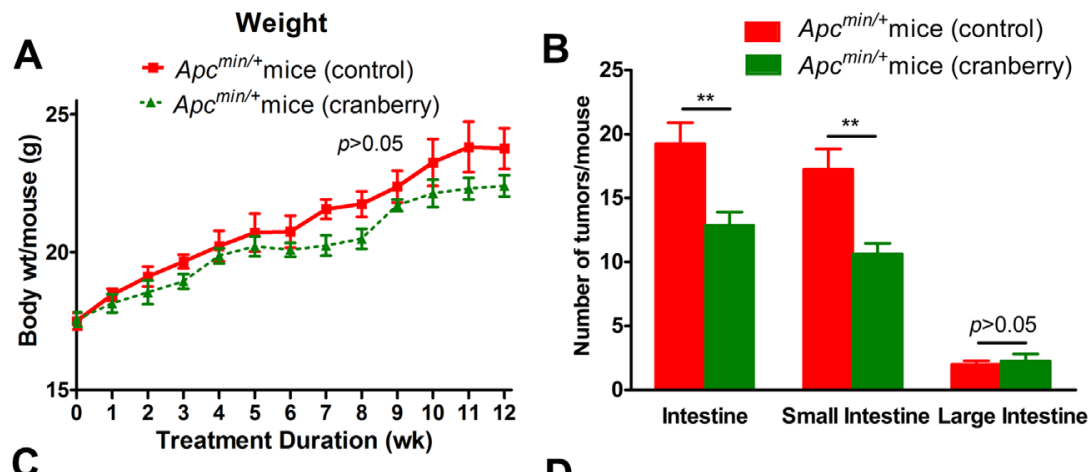

C

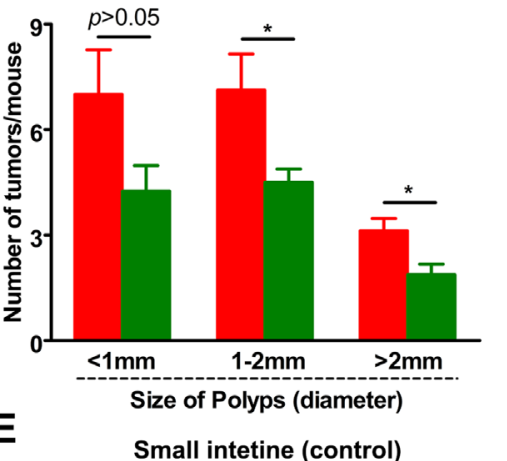

D
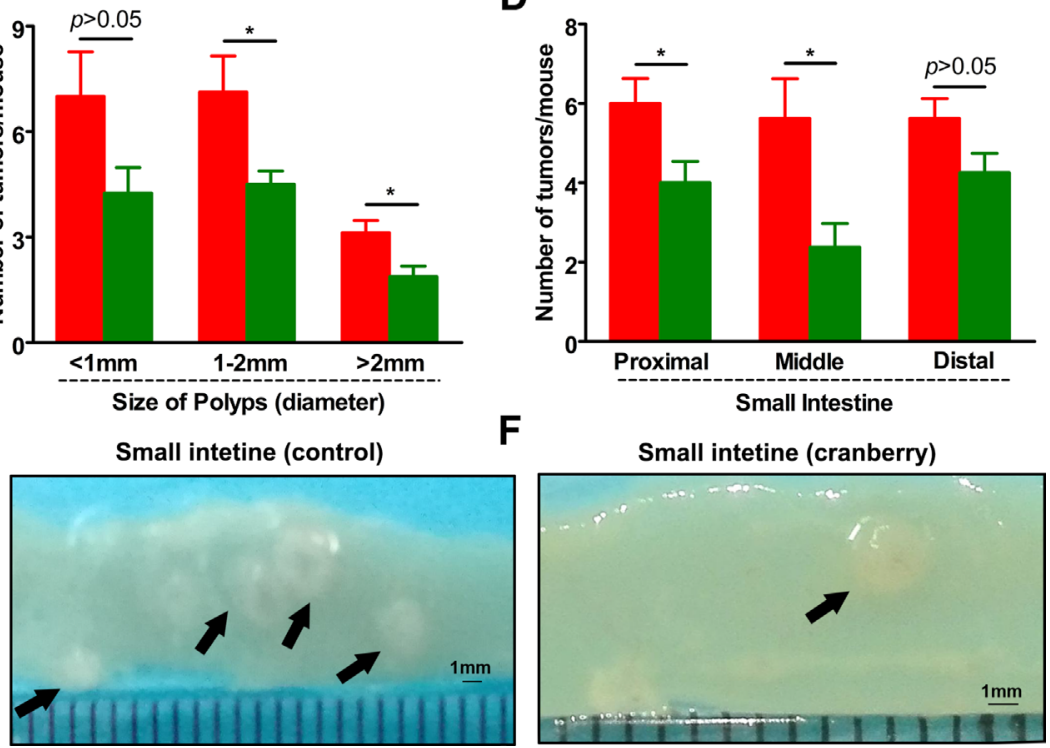

Figure 1: Cranberry ingestion inhibited intestinal tumor development. (A) Dietary feeding of cranberry did not affect body weight gain in $A p c^{\mathrm{min} / \mathrm{t}}$ mice. (B) The numbers of polyps per mouse in the small intestine and colon in both groups were listed. (C-D) Cranberry supplementation decreased the number of larger polyps $(>1 \mathrm{~mm})$ with the most prominent effect in proximal and middle sections of small intestine. Columns represented as mean from the ten mice in each group, bars represented as standard deviation. ${ }^{* *} p<0.01$ and ${ }^{*} p<$ 0.05 , cranberry diet-fed $v s$ basal diet-fed $A p c^{\mathrm{min} / \mathrm{t}}$ mice. $(\mathbf{E}-\mathbf{F})$ The representative gross appearance of intestinal tumors from both groups was shown after 12-week experiment. 

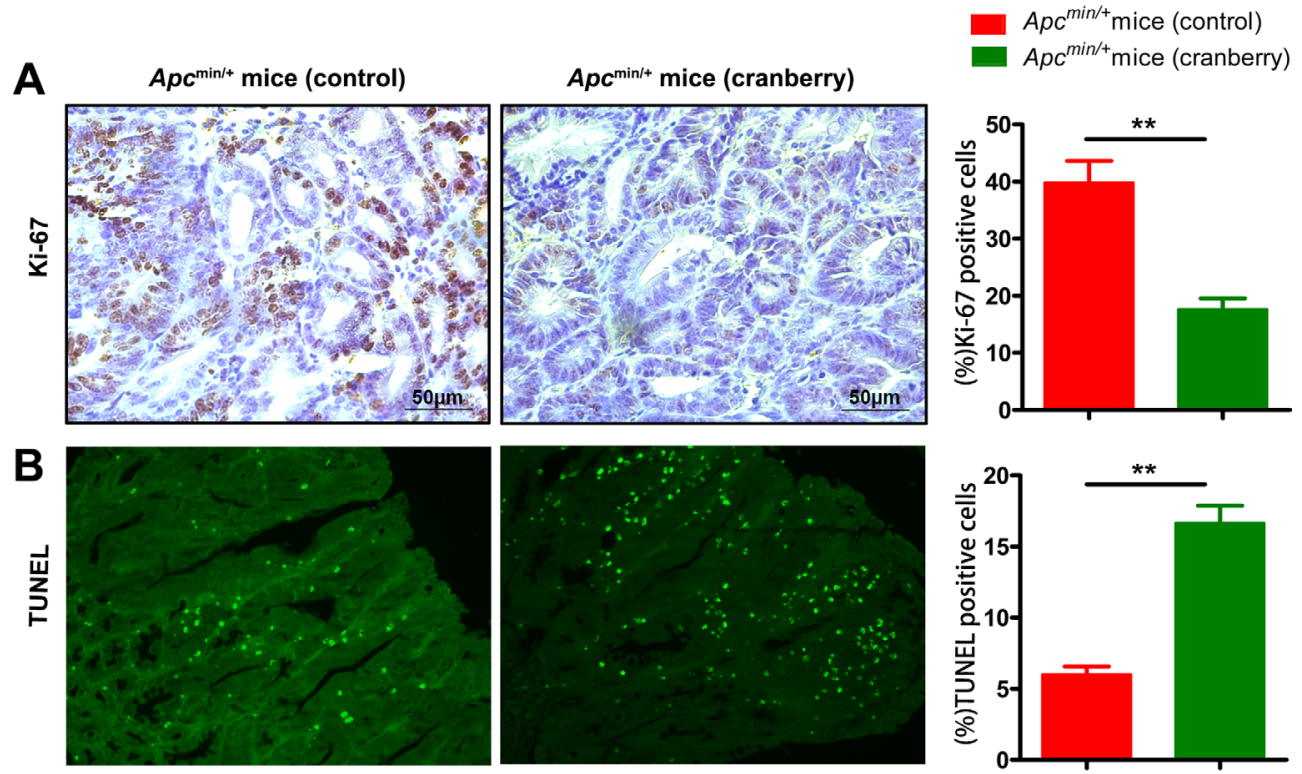

Figure 2: Cranberry supplementation inhibited proliferation and promoted apoptosis in intestinal tumors. (A-B) Middle small intestinal sections from basal diet-fed and cranberry diet-fed mice were stained with Ki-67 and TUNEL, wherein brownstained cells demonstrated Ki-67 immunostaining (400× magnifications), green staining represented apoptotic cells (200× magnifications). Scale bars, $50 \mu \mathrm{m}$. Both assays were quantified by counting percent positive rate of tumor cells' nuclei at 5 randomly selected fields from each section. Values are means from ten mice in each group with their standard errors. ${ }^{* *} p<0.01$, cranberry diet-fed $v s$ basal diet-fed $A p c^{\text {min } /+}$ mice. $n=10 /$ group.

\section{A}

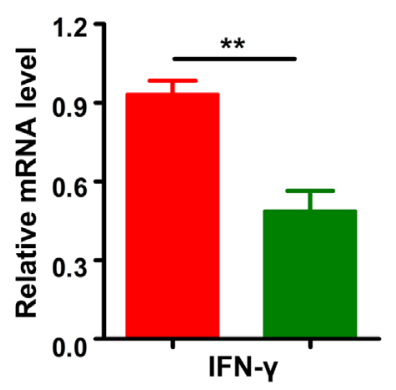

B

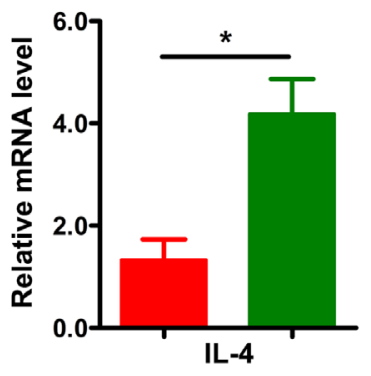

$A p c^{\mathrm{min} / \mathrm{+}}$ mice (control)

$A p c^{\mathrm{min} / \mathrm{t}}$ mice (cranberry)
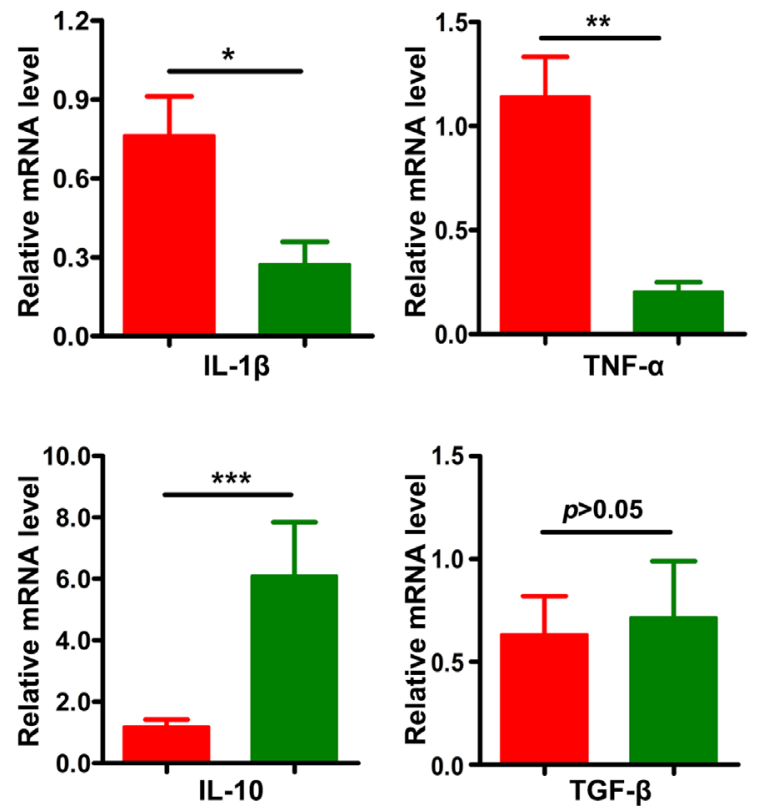

Figure 3: Dietary cranberry relieved chronic inflammation in colon. (A-B) RNA was extracted from tumor-adjacent tissue in colon for real-time quantitative PCR analysis. The relative mRNA expression of inflammatory cytokines including IFN- $\gamma$, IL- $1 \beta$, TNF- $\alpha$, IL-4, IL-10 and TGF- $\beta$ was presented. Data was expressed as fold change compared with the control group $(100 \%) .{ }^{*} p<0.05,{ }^{* *} p<0.01$, ${ }^{* * *} p<0.001$, cranberry diet-fed $v s$ basal diet-fed $A p c^{\mathrm{min} /+}$ mice. $n=10 /$ group. 
$33.11 \pm 4.58, p<0.001$, Figure 4C). As a major component of inner mucus layer, MUC2 mucin produced by goblet cells was up-regulated by cranberry feeding $(16.13 \pm 2.71$ vs $27.71 \pm 1.83, p<0.001$, Figure 4D). Cranberry-treated mice were associated with longer villi and deeper crypts compared with control mice (Figure 4 and Supplementary Figure 1). The results suggested that cranberry might be effective in influencing the number of goblet cells and gut mucin production, and ultimately enhancing the integrity of the gut barrier.

\section{Cranberry feeding increased caecal concentrations of SCFAs in $A p c^{\mathrm{min} /+}$ mice}

Fibre containing diet influences the production and absorption of SCFAs, particularly propionic and butyric acids. SCFAs, which are formed by microbial degradation of dietary fibres in colon, have capacity to reduce lowgrade inflammation [43, 44]. In this experiment, we found that the addition of cranberry diet to $A p c^{\mathrm{min} /+}$ mice made no significant difference in the weight of caecal content ( $p>0.05$, Table 1$)$. The concentration of acetic acid was highest, followed by propionic and butyric acids. These caecal concentrations of the three SCFAs were 2.9-3. 2-fold higher than that of the control group $(p<0.05)$. The observed results highlighted that SCFAs had been postulated to elucidate the underlying link between fibre containing diet and prevention of CRC.

\section{Cranberry feeding down-regulated EGFR signaling in $A p c^{\mathrm{min} /+}$ mice}

The effects of cranberry feeding on EGFR signaling pathway involved in tumor development were
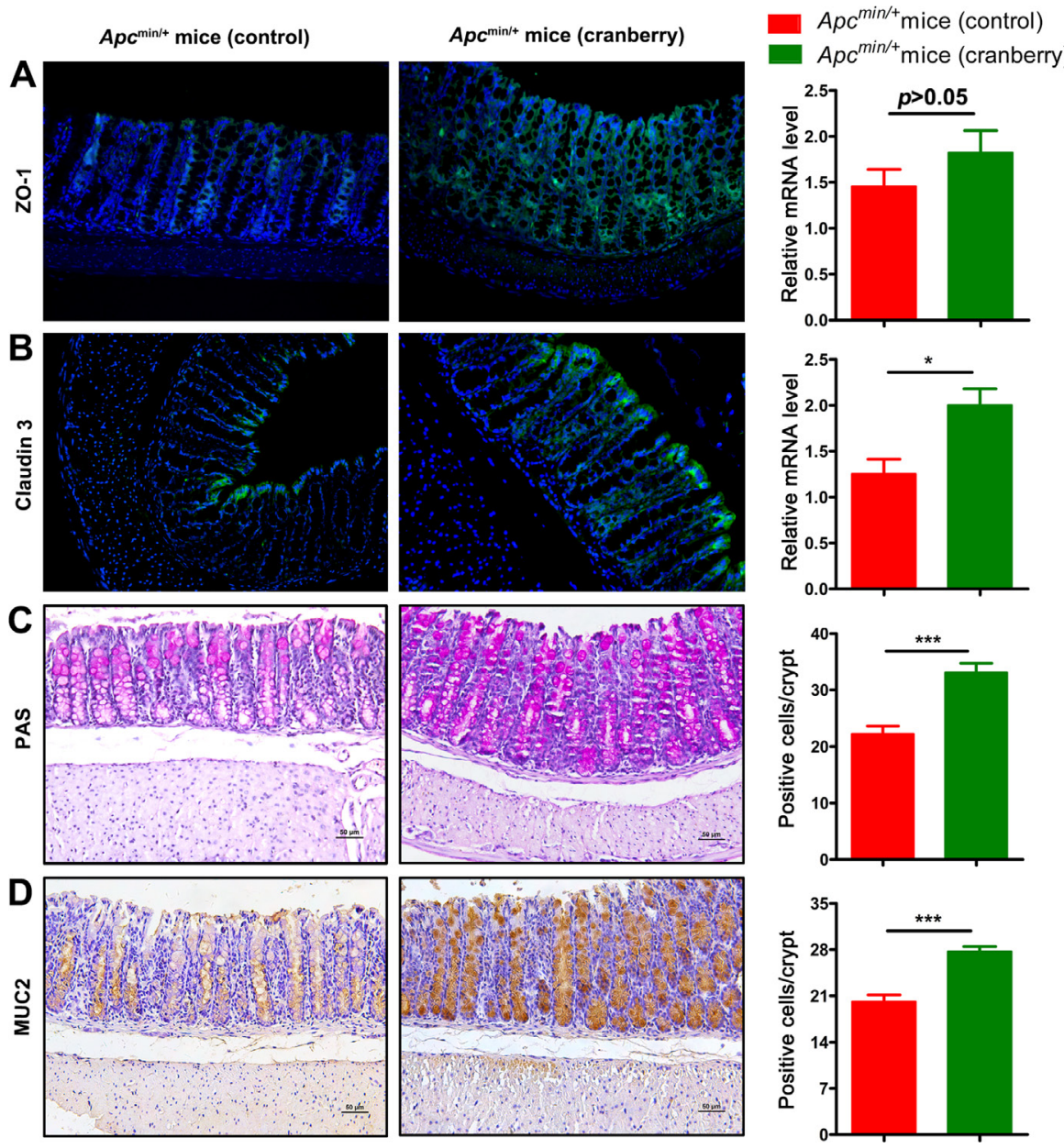

Figure 4: Cranberry supplementation protected colonic barrier function. (A) Paraffin-embedded colon tissues were used to determine ZO-1 distribution by immunofluorescence stain using an anti-ZO-1 antibody and FITC-labeled secondary antibody and visualized using fluorescence microcopy (green staining; 200×). Nuclei were stained with DAPI (blue staining). Real-time PCR analysis of ZO-1 expression in the cell membranes of colonic epithelial cells was shown. (B) Claudin 3 distribution was showed analogously by immunofluorescence stain and real-time PCR. (C-D) PAS and MUC2 in the colon tissues of both groups were assessed using immunostaining $(200 \times)$. Scale bars, $50 \mu \mathrm{m}$. The numbers of positively stained cells were determined by counting the absolute number of positive stained cells in at least 300 colonic crypts for each mouse. ${ }^{* * *} p<0.001,{ }^{*} p<0.05$, cranberry diet-fed $v s$ basal diet-fed $A p c^{\mathrm{min} /+}$ mice. $n=10 /$ group. 
Table 1: Effects of cranberry diet on the weight of caecal content and SCFAs concentrations

\begin{tabular}{|c|c|c|c|c|}
\hline & \multicolumn{2}{|c|}{$A p c^{\min /+}$ mice (control) } & \multicolumn{2}{|c|}{$A p c^{\mathrm{min} /+}$ mice (cranbery) } \\
\hline & Mean & SEM & Mean & SEM \\
\hline Caecal content weight $(\mathrm{g})$ & 0.15 & 0.07 & 0.06 & 0.05 \\
\hline Acetate $(\mu \mathrm{M} / \mathrm{g} W W)$ & 7.36 & 1.68 & 23.74 & $8.74^{*}$ \\
\hline Propionate $(\mu \mathrm{M} / \mathrm{g} \mathrm{WW})$ & 5.45 & 1.14 & 15.92 & $5.54^{*}$ \\
\hline Butyrate ( $\mu \mathrm{M} / \mathrm{g} W W)$ & 3.71 & 0.78 & 11.47 & $4.05^{*}$ \\
\hline
\end{tabular}

WW, wet weight. SCFAs, short-chain fatty acids. Values represented the means with their standard errors, $n=10 /$ per group. ${ }^{*} p<0.05$.

further investigated. Immunostaining supported that phosphorylation of EGFR and Akt in intestinal tumors from distal small intestine were suppressed by cranberry supplementation. It was observed that the average percentages of p-EGFR-positive cells in cranberry diet-fed and basal diet-fed groups were $16.67 \pm 4.11$ vs $32.33 \pm 4.03$ $(p<0.05$, Figure 5A) and p-Akt stained cells were 44.33 \pm 8.99 vs $73.33 \pm 5.91(p<0.05$, Figure 5B). However, immunostaining showed that there was no difference in the activation of $\mathrm{Wnt} / \beta$-catenin signaling between the two groups ( $p>0.05$, Supplementary Figure 2).

Western blot analyses were consistent with immunostaining results. We compared the relative density of the protein band for total EGFR, p-EGFR, total Akt, and p-Akt to those of internal control bands from the same mouse's tumor tissue lysate. The fold changes of the average protein band ratio in cranberry diet-fed group were calculated since the control group' was set as 100\%. The levels of phosphorylated EGFR and Akt were reduced in tumors of cranberry diet-fed group when compared to controls $(p<0.001 ; p<0.05$, Figure 5C). No differences were found in the total amounts of EGFR and Akt. All these results suggested that cranberry supplementation suppressed the activation of EGFR signaling in $A p c^{\mathrm{min} /+}$ mice.

\section{DISCUSSION}

It is increasingly perceived that dietary components have been linked with the prevention of CRC [25, 45]. Among them, fruits and vegetables have emerged to fulfil important roles in improving health. Berries promisingly have raised interests for their high phytochemical and fibre content [46-48]. The present study showed the inhibitory effects of feeding cranberry supplemented diet on the intestinal polyposis in the $A p c^{\mathrm{min} /+}$ mouse model, which justified further research about how berry phytonutrients prevented CRC in vivo. It was highlighted that dietary cranberry would beneficially modulate colonic inflammation and caecal SCFAs, inhibit activation of EGFR signaling and regulate proliferation and apoptosis of tumour cells possibly due to the fermentable fibre components and phenolic compounds in berry.
Recent years researchers have raised interests in botanical dietary therapeutics, corresponding with an association that plants, fruits and vegetables contain intricate components with multifunctional roles, which may better prevent or postpone elusive chronic diseases than single active pharmaceutical ingredients. As chemopreventive dietary constituent, cranberry fruit (Vaccinium macrocarpon Ait.) is a promising dietary source of phytochemicals, because of richness in flavonoids such as anthocyanins glycosides, flavonol glycosides, and proanthocyanidin (PAC) oligomers; organic and phenolic acids such as benzoic acid and ursolic acid, etc. [49-51]. In particular, proanthocyanidinsin cranberries contain "A-type" bonds compared with the B-type PACs present in most other fruits [46]. Polyphenols from cranberry have emerged to fulfil putative roles in chronic diseases, i.e. type 2 diabetes, heart disease and various cancers for their high antioxidant capacities [52]. Cranberry "A-type" PAC could better contribute to pathogenic Escherichia coli agglutination and then decrease the invasion of enterocytes [53]. Most of procyanidins are degraded into multiple phenolic compounds as biologically active forms under the action of gut microbiota. Furthermore, dietary fiber of cranberry may influence the gut microbiota, which is essential to intestinal barrier function [25]. Cranberry bioactives are possible contributors to limit carcinogenesis in a complementary fashion. In this study, the consumption patterns of CRC patients are imitated appropriately, because $20 \%$ dietary supplementation level is achievable for human being [5456], which offers a fine prospect in achievement transform. In addition, effects require further elaboration to determine the dose-response relationships of lower levels of cranberry supplementation to health benefits.

Chronic inflammation and excessive immune signaling receive attention for the causes of dysregulation of cell proliferation in $A p c^{\mathrm{min} /+}$ mice, which accompanied with the up-regulation of inflammation genes [57]. The levels of intestinal inflammation cytokines are used to assess the development and progression of inflammatory responses in CRC patients [58, 59]. The present study found that inflammatory mediators of the colon were regulated by dietary cranberry in $A p c^{\mathrm{min} /+}$ mice, which 
exhibited a reduced intestinal inflammatory response. These mice fed by cranberry had a lower level of inflammation. Phytochemicals including fibre and phenolic compounds in cranberry are known to influence inflammatory responses by way of exerting a myriad of cellular effects [60-62]. These effects include release of antioxidant potential and induction of an anti-inflammatory effect by modulating NF- $\mathrm{B}$ signaling $[63,64]$. Therefore, the combined effects of phytochemicals in cranberry diet beneficially attenuated intestinal immune response in $A p c^{\mathrm{min} /+}$ mice. Gut barrier separates the host from luminal microorganisms and noxious molecules while absorbing nutrients. Mucus layer, mainly comprising MUC2, is the front line of innate immune defense. Gut barrier properties may be destroyed due to unbalancing pro- and anti-inflammatory mediators in the mucosa $[42,65,66]$. In this study, cranberry ingestion stimulated goblet cells to produce MUC2 and promoted epithelial intercellular junctions to maintain gut barrier.
Substantial evidence indicates that a Western-style diet low in dietary fiber is associated with a high risk of colorectal carcinogenesis [67]. Following the consumption of cranberry fibre, the anti-cancer potential may have been driven by microbial metabolic products, such as SCFAs [68]. SCFAs are the end productions of non-digestible dietary carbohydrates under the fermentation of intestinal microflora [22]. SCFAs, particularly butyrate, have been regarded as chemopreventive agents which play plurifunctional roles in the colonocytes. The current working hypothesis is that butyrate provides energy for epithelial cells $[69,70]$ and enhances gut barrier integrity [71]. Furthermore, butyrate exerts anti-inflammatory effects within epithelium through the modulation of inflammatory signaling pathways including the inhibition of histone deacetylase activity. All these actions play a comprehensive role in influencing the dynamic balance of gut microbiota towards commensal bacteria such as butyrate-producing bacteria [70, 72, 73]. In the present study, as a consequence of increased microbial
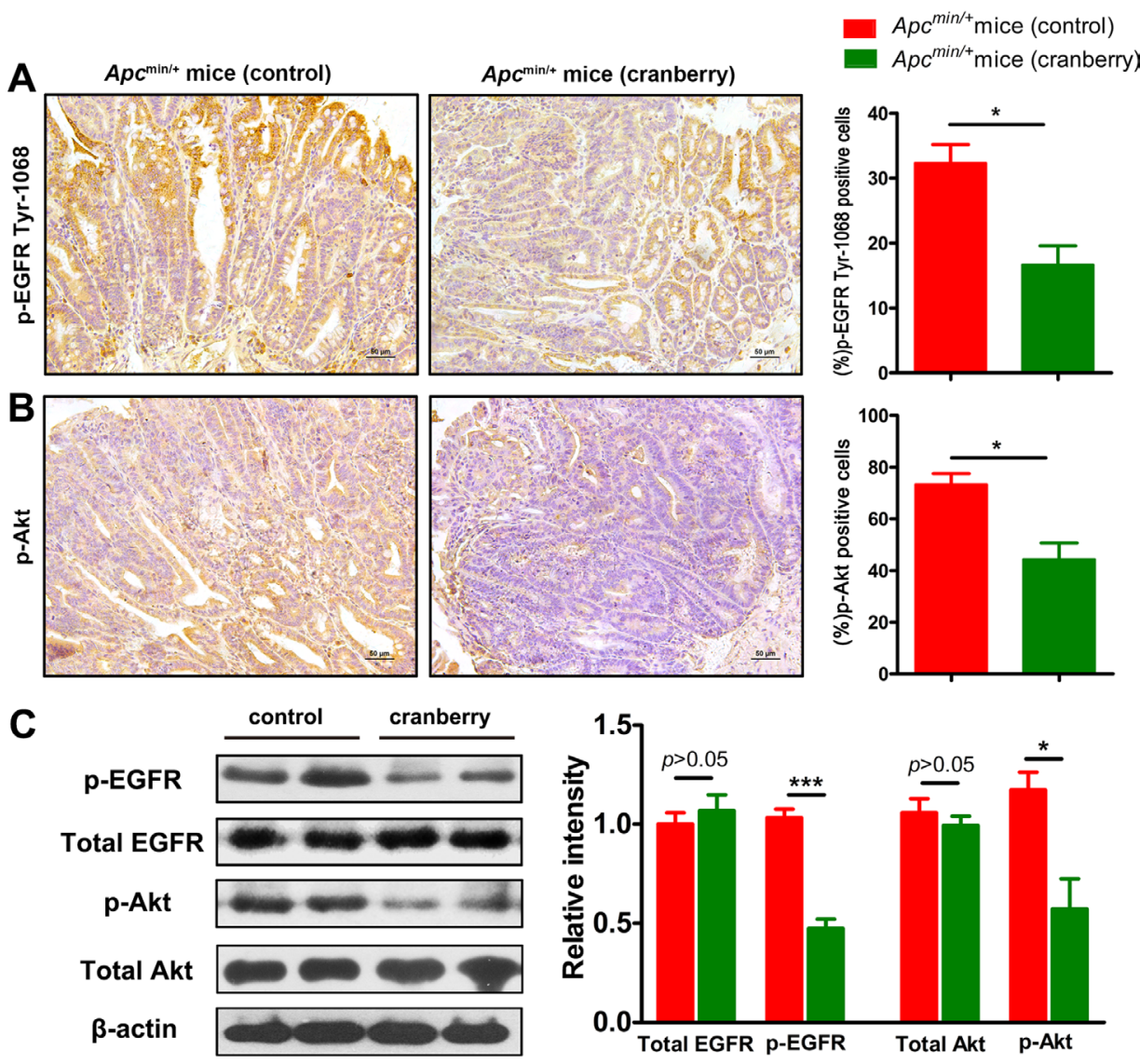

Figure 5: Cranberry supplementation down-regulated EGFR signaling pathway in intestinal tumors. (A-B) p-EGFR and p-Akt from the diatal small intestine of both groups were shown by immunohistochemical staining $(400 \times)$. Scale bars, $50 \mu \mathrm{m}$. Data were semiquantified as mean percentage of positive cells at five randomly selected fields. (C) Protein lysates from tumors were analyzed by Western blot analysis using anti-total EGFR and p-EGFR antibodies, and anti-total Akt and p-Akt antibodies, which anti- $\beta$-actin antibody was used as an internal control for total protein. The fold changes were calculated by comparing the relative densities of total EGFR, p-EGFR and p-Akt bands to corresponding $\beta$-actin bands from the same mouse. Proteins were quantified by densitometry using Image $J$ to calculate the average ratio, and the average ratio in control was set as $100 \%$. Columns, means from at least six mice in each group; bars, standard deviation. ${ }^{*} p<0.05,{ }^{* * *} p<0.001$, cranberry diet-fed $v s$ basal diet-fed $A p c^{\min /+}$ mice. $n=8 /$ group. 
activity, caecal SCFA concentrations (acetate, propionate and butyrate) were increased in cranberry-supplemented group compared to the control. And, we did not find that proanthocyanidin- rich dietary fiber could increase the caecal content weight similar to those in other studies [74, 75]. Furthermore, butyrate has been implicated in the decreased expression of pro-inflammatory mediators, as well as increased expression of anti-inflammatory mediators, which was observed by Jakobsdottir G et al. [74]. Butyrate and its role in CRC prevention need to be excavated for its clinical use any further.

Anthocyanins, proanthocyanidins, and flavonol glycosides have demonstrated enhanced antiproliferative interactions synergistically or additively [16, 76]. In the present study, daily consumption of cranberry for 12 weeks reduced proliferation and induced apoptosis in colorectal tissue of $A p c^{\mathrm{min} /+}$ mice. The activation of EGFR is essential for accelerating cell cycle progression, promoting cell proliferation and impeding cell apoptosis by phosphorylating (activation) its downstream targets (PI3K/AKT and Ras-ERK) in many tissue types [77]. Activating EGFR/AKT signaling is known to promote tumorigenesis, and EGFR signalinghas regarded as a promising target to control tumor development [16]. In this study, the dietetic treatment with cranberry was found to beneficially regulate cell proliferation and apoptosis, and meanwhile impede the phosphorylation of EGFR and its downstream Akt in intestinal tumors in $A p c^{\mathrm{min} /+}$ mice, compared with basal diet. However, it remains to be determined the mechanisms of the inhibitory effects of EGFR pathway by cranberry nutrients.

Overall, this study suggested that dietary administration of cranberry inhibited intestinal tumor development in the $A p c^{\mathrm{min} /+}$ mouse model. Cranberry exerted its effects probably by decreasing inflammatory cytokine production and promoting intestinal barrier function while simultaneously regulating EGFR signaling, associated with intestinal proliferation and apoptosis for its fiber-derived SCFAs. In summary, an appropriate dietary intervention, as a new treatment strategy, in combination with pharmaceuticals, may have benefit on preventing intestinal cancer in high-risk populations.

\section{MATERIALS AND METHODS}

\section{Animals and diets}

Female $A p c^{\mathrm{min} /+}$ mice aged 4 weeks on C57BL/6J background ( $n=20$ ) were obtained from the Animal Model Institution of Nanjing University, P. R. China. The genotypes of the mice were screened using PCR methods to identify Min genotype [78]. Animals were housed in humidity- and temperature-controlled plastic cages with 12/12 h light/dark cycle (temperature: $25^{\circ} \mathrm{C}$; humidity: $50 \%$; lights off at 18:00) under specific pathogen free
(SPF) circumstances. The animals were randomly divided into two groups (10 mice per group, 5 mice per cage). Control group was fed AIN-93G control diet continuously while the cranberry-treated group was fed $20 \%$ cranberry powder (wt/wt) mixed in AIN-93G diet ad libitum for 12 weeks by reference to dosages in published reports $[22,48,56]$. Freeze-dried whole cranberry powder was purchased from commercial vendor Peak Season Foods (Nampa, Idaho, USA), and its nutrition facts were showed in Table 2. The rodents were weighed once a week and monitored daily for any signs of toxicity throughout the 12 week treatment period. The animals were starved overnight and then killed by $\mathrm{CO}_{2}$ inhalation at the end of 12 weeks. All the animals were starved overnight before sacrifice in order to clean the bowel and obtain intestinal tissues more easily. Caecal contents were snap-frozen and stored in refrigerators at $-80^{\circ} \mathrm{C}$ until analysis for SCFA content. All experimental procedures were performed under the guidelines of the Institutional Animal Care and Use Committee at Tianjin Medical University, Tianjin, P. R. China.

\section{Measurement of tumors and tissue collection}

The intestine was immediately excised from each mouse after sacrifice as previously described [79]. The intestines of all mice were opened longitudinally and then rinsed well with sterile ice-cold PBS solution to remove the intestinal contents. The small intestine was divided into three equal sections, i.e., proximal, middle, and distal, and the colon. Afterwards, all tissue sections of the small intestine and colon were viewed and recorded by the same veterinary pathologist blinded to the experiment with a steel rule under an Olympus SZX7 stereo dissecting microscope. The total numbers of polyps in each section were counted. The size of each polyp was measured and categorized as small ( $<1 \mathrm{~mm})$, medium (1-2 mm), or large $(>2 \mathrm{~mm})$. Swiss-rolled middle small intestine and colon as well as hepatic and kidney tissues were fixed in $10 \%$ neutral-buffered formalin until further analysis for preparing Paraffin-embedded tissue sections. Paraffinembedded intestinal Swiss rolls containing tumors were stained with hematoxylin and eosin (H\&E) for tumor stage or used for immunohistochemical staining. Adenomas from middle small intestinal tissues were excised and snap-frozen rapidly, and stored at $-80^{\circ} \mathrm{C}$ for later analysis of protein expression.

\section{Periodic acid Schiff (PAS) staining}

1\% Periodic acid solution (Sigma-Aldrich) was used to incubate deparaffinised colonic sections for $10 \mathrm{~min}$. And then Schiff reagent (Sigma-Aldrich) was used for incubation for $40 \mathrm{~min}$. The PAS-stained sections were counterstained with Hematoxylin for 2-5 min. Extensive PBS solution was used to rinse well between each step. 


\begin{tabular}{|c|c|}
\hline \multicolumn{2}{|l|}{ Serving Size 10 Grams } \\
\hline \multicolumn{2}{|l|}{ Serving Per Container 23} \\
\hline \multicolumn{2}{|l|}{ Amount Per Serving } \\
\hline Calories 38 & Calories from Fat 0 \\
\hline & \% Daily Values* \\
\hline Total Fat $0 \mathrm{~g}$ & $0 \%$ \\
\hline Saturated Fat $0 \mathrm{~g}$ & $0 \%$ \\
\hline \multicolumn{2}{|l|}{ Trans Fat $0 \mathrm{~g}$} \\
\hline Cholesterol $0 \mathrm{mg}$ & $0 \%$ \\
\hline Sodium $2 \mathrm{mg}$ & $0 \%$ \\
\hline Total Carbohydrate $9 \mathrm{~g}$ & $3 \%$ \\
\hline Dietary Fiber 2 g & $8 \%$ \\
\hline \multicolumn{2}{|l|}{ Sugars $5 \mathrm{~g}$} \\
\hline Protein $0 \mathrm{~g}$ & $0 \%$ \\
\hline Vitamin A $1 \%$ & Vitamin C 3\% \\
\hline Calcium $0 \%$ & Iron $0 \%$ \\
\hline
\end{tabular}

*Percent Daily Values are based on a 2,000 calorie diet.

\section{Histopathology and immunohistochemistry}

Formalin-fixed, paraffin-embedded intestinal tissue blocks were cut into $4-\mu \mathrm{m}$ slices by a microtome for immunostaining. Thereafter, intestinal tissue slices were deparaffinised in xylene and rehydrated in graded ethanol. Antigens were retrieved in Antigen Unmasking Solution (Vector laboratories, Inc. Burlingame, CA, USA) for $15 \mathrm{~min}$. Endogenous peroxidase activity was quenched by immersing in 3\% hydrogen peroxide for $10 \mathrm{~min} .5 \%$ goat serum was used to block non-specific binding in Trisbuffered saline for $1 \mathrm{~h}$ at room temperature. The tissue sections were incubated with primary antibodies, rabbit anti-Ki-67 (ab16667, Abcam, Cambridge, MA, USA), phospho-EGFR (Tyr1068) (CST3777, Cell Signaling technology, Boston, MA, USA), phospho-Akt (p-Akt, Ser473) (CST4060, Cell Signaling technology, Boston, MA, USA), $\beta$-catenin (Santa Cruz Biotechnology, Inc., Santa Cruz, CA, USA), cyclin D1(ab134175, Abcam, Cambridge, MA, USA) and rabbit anti-MUC2 (Santa Cruz Biotechnology, Inc), overnight at $4^{\circ} \mathrm{C}$ in a humiditycontrolled chamber. Washed sections were then incubated with appropriate horseradish peroxidase (HRP)-labeled second antibodies for $30 \mathrm{~min}$ followed by incubation with 3, 3'-diaminobenzidine for color development. The sections were viewed blindly ( $400 \times$ or $200 \times$ magnification) under the light microscope by the same pathologist (YJZ). At least five fields searched for each tumor without any overlap were viewed to count the numbers of positive cells (brown staining). All tumors in each section were analyzed to calculate the final numbers of positive cells. Hence, the proliferation index was determined as the number of Ki-67positive cells $\times 100 /$ total number of cells.

\section{TUNEL assay}

Terminal deoxynucleotidyl transferase dUTP nick end labeling (TUNEL) assay was performed to detect apoptosis in tumors of middle small intestine. Paraffin-embedded sections containing tumors were deparaffinized, and stained for apoptotic nuclei using an In Situ Cell Death Detection Kit (Roche Diagnostics) based on manufacturer's protocols. To quantitate the average number of apoptotic cells in each group, five fields from each section were randomly chosen with $200 \times$ magnification ( $n=10$ / group).

\section{Real-time quantitative PCR analysis}

Total RNA was extracted from tumor-adjacent tissues in distal small intestine and colonusing the RNeasy mini kit (Qiagen, Carlsbad, CA, USA) and reversetranscribed using the TIANScript Reverse Transcription Kit (TIANGEN, Inc. Beijing, China). Real-time PCR was performed to measure the levels of cytokines, ZO-1 and claudin 3 using Taqman Gene Expression Master Mix. The Oligonucleotide primer sequences were showed in Table 3. Glyceraldehyde-3-phosphate dehydrogenase (GAPDH) was used as a house-keeping gene to normalize the relative abundance of targeted genes at the level of mRNAs. Realtime polymerase chain reaction (PCR) was carried out for amplification on a StepOne Plus real time PCR instrument (Applied Biosystems, Carlsbad, CA) following the manufacturer's recommendations with all cDNA products analyzed in triplicate. Gene expression of each transcript was analyzed using the standard $\Delta \Delta \mathrm{CT}$ method to calculate fold-changes which were normalized to the housekeeping genes for each sample. 
Table 3: Gene sequences of primers in the present study

\begin{tabular}{|c|c|}
\hline Primers & Sequence \\
\hline \multirow[t]{2}{*}{ GAPDH } & Forward 5'-TGTGTCCGTCGTGGATCTGA-3' \\
\hline & Reverse 5'-CCTGCTTCACCACCTTCTTGA-3' \\
\hline \multirow[t]{2}{*}{ IFN- $\gamma$} & Forward 5'-GCATCTTGGCTTTGCAGCT-3' \\
\hline & Reverse 5'-CCTTTTTCGCCTTGCTGTTG-3' \\
\hline \multirow[t]{2}{*}{ IL-1 $\beta$} & Forward 5'-GTGGCTGTGGAGAAGCTGTG-3' \\
\hline & Reverse 5'-GAAGGTCCACGGGAAAGACAC-3' \\
\hline \multirow[t]{2}{*}{$\mathrm{TNF}-\alpha$} & Forward 5'-ACTCCAGGCGGTGCCTATG-3' \\
\hline & Reverse 5'-GAGCGTGGTGGCCCCT-3' \\
\hline \multirow[t]{2}{*}{ IL-4 } & Forward 5'-CGAATGTACCAGGAGCCATATC-3' \\
\hline & Reverse 5'-TCTCTGTGGTGTTCTTCGTTG-3' \\
\hline \multirow[t]{2}{*}{ IL-10 } & Forward 5'-TGGACAACATACTGCTAACCG-3' \\
\hline & Reverse 5'-GGATCATTTCCGATAAGGCT-3' \\
\hline \multirow[t]{2}{*}{ TGF- $\beta$} & Forward 5'-GCTGAACCAAGGAGACGGAAT-3' \\
\hline & Reverse 5'-GCTGATCCCGTTGATTTCCA-3' \\
\hline \multirow[t]{2}{*}{$\mathrm{ZO}-1$} & Forward 5'-GGGCCATCTCAACTCCTGTA-3' \\
\hline & Reverse 5'-AGAAGGGCTGACGGGTAAAT-3' \\
\hline \multirow[t]{2}{*}{ claudin 3} & Forward 5'-CCTGTGGATGAACTGCGTG-3' \\
\hline & Reverse 5'-GTAGTCCTTGCGGTCGTAG-3' \\
\hline
\end{tabular}

\section{Western blot analysis}

Tumors from distal small intestinal tissues were excised and stored in refrigerators at $-80^{\circ} \mathrm{C}$. The total cellular lysates of these adenomas were prepared by sonication and RIPA buffer, during which $10 \mu \mathrm{L} / \mathrm{mL}$ of proteinase inhibitor cocktail and phosphatase inhibitor cocktail (Sigma, St. Louis, MO) were added respectively. After homogenization and centrifugation $\left(12,000 \mathrm{~g}, 4^{\circ} \mathrm{C}, 15 \mathrm{~min}\right)$, protein concentration of the resulting lysate was determined by Bicinchoninic acid protein assay (Thermo Scientific Inc.). Proteins were separated by SDS-polyacrylamide gel electrophoresis and then transferred onto a PVDF membrane. Primary antibodies, including rabbit polyclonal antibodies against EGFR, phospho-EGFR, Akt, and phospho-Akt, were used to perform western blot, and later blotted with secondary antibodies (anti-rabbit IgG peroxidase conjugates). Anti- $\beta$ actin antibody was employed to assess total protein loading of cellular lysate. The chemiluminescent signal of the PVDF membrane was detected by X-ray films with ECL (GE Healthcare, Bucks, UK) and analyzed with an image processor program (Image J), which contributed to determine the intensity of the targeted band and internal control band in each individual mouse.

\section{Caecal SCFAs detection using gas chromatography}

The SCFAs including acetic, propionic and butyric acids in the caecal contents of mice were analyzed using gas chromatography (GC) as previously described with slight modification [56, 74]. Briefly, SCFAs were extracted from frozen caecal contents and injected into the GC system (Agilent 7890A) equipped with a HP-INNOWAX capillary column $(30 \mathrm{~m} \times 0.25 \mathrm{~mm} \times 0.25 \mu \mathrm{m}$; Agilent Technologies, USA) for chromatographic separation. Samples (1 uL each) were injected into the capillary column by split-injection mode with a split ratio of 1:1. Nitrogen was used as carrier gas at a constant flow of $1 \mathrm{~mL} / \mathrm{min}$. Injector temperature was maintained at $220^{\circ} \mathrm{C}$. After an initial temperature of $70^{\circ} \mathrm{C}$ for $2 \mathrm{~min}$, the oven temperature was increased to $150^{\circ} \mathrm{C}$ at a rate of $10^{\circ} \mathrm{C} / \mathrm{min}$, and then increased by $15^{\circ} \mathrm{C} /$ min and finally kept at $230^{\circ} \mathrm{C}$ for 5 min. Different peaks were identified according to their respective retention times using acetic, propionic and butyric acids GC standards (Sigma-Aldrich, USA). Agilent Chemstation software was used for data collection.

\section{Statistical analysis}

All continuous variables were presented as mean \pm SEM. Statistical comparisons of the multiplicity of intestinal tumors were analyzed by two-tailed Student's $t$-test with the GraphPad Prism version 5.00 (GraphPad Software, Inc.). The percentage of positively stained cells and the fold changes of the ratio for the relative density of bands in western blot analysis were performed using Student's $t$-test. Student's $t$-test was also used to determine differences in body weight between groups. Differences were considered statistically significant with $p<0.05$. 


\section{Abbreviations}

Apc, adenomatous polyposis coli gene; CRC, colorectal cancer; EGFR, epidermal growth factor receptors; FAP, familial adenomatous polyposis; GAPDH, glyceraldehyde-3-phosphate dehydrogenase; GC, gas chromatography; HRP, horseradish peroxidase; IL, interleukin; IFN, interferon; Min, multiple intestinal neoplasia; MUC, mucin; PACs, A-type proanthocyanidins; PAS, Periodic acid-schiff; PBS, Phosphate buffer saline; PCR, real-time polymerase chain reaction; SCFA, short chain fatty acid; SPF, specific pathogen free; TNF, tumor necrosis factor; TUNEL, terminal deoxynucleotidyl transferase dUTP nick end labeling assay; ZO-1, zona occludens 1 .

\section{Author Contributions}

Jin DC, Wang BM, and Cao HL designed the research; Jin DC, Liu TY, Dong WX, Wang SN, Zhang YJ and Xie RX performed the experiments; Jin DC and Cao HL wrote the paper; all authors were involved in the final approval of the article.

\section{CONFLICTS OF INTEREST}

The authors have no conflicts of interest.

\section{FUNDING}

This study was supported by the grants ( 81470796 , and 81570478) from the National Natural Science Foundation of China, the grant (15JCZDJC36600, and 17JCYBJC24900) from Tianjin Research Program of Application Foundation and Advanced Technology of China, and the grant from Technology Foundation for Selected Overseas Scholar, Ministry of Human Resources and Social Security of China.

\section{REFERENCES}

1. Siegel RL, Miller KD, Jemal A. Cancer statistics, 2015. CA Cancer J Clin. 2015; 65:5-29.

2. Torre LA, Bray F, Siegel RL, Ferlay J, Lortet-Tieulent J, Jemal A. Global cancer statistics, 2012. CA Cancer J Clin. 2015; 65:87-108.

3. Moskal A, Freisling H, Byrnes G, Assi N, Fahey MT, Jenab M, Ferrari P, Tjønneland A, Petersen KE, Dahm CC, Hansen CP, Affret A, Boutron-Ruault MC, et al. Main nutrient patterns and colorectal cancer risk in the European Prospective Investigation into Cancer and Nutrition study. Br J Cancer. 2016.

4. Blumberg JB, Camesano TA, Cassidy A, Kris-Etherton P, Howell A, Manach C, Ostertag LM, Sies H, Skulas-Ray A,
Vita JA. Cranberries and their bioactive constituents in human health. Adv Nutr. 2013; 4:618-32.

5. Déziel B, MacPhee J, Patel K, Catalli A, Kulka M, Neto C, Gottschall-Pass K, Hurta R. American cranberry (Vaccinium macrocarpon) extract affects human prostate cancer cell growth via cell cycle arrest by modulating expression of cell cycle regulators. Food Funct. 2012; 3:556-64.

6. Déziel BA, Patel K, Neto C, Gottschall-Pass K, Hurta RA. Proanthocyanidins from the American Cranberry (Vaccinium macrocarpon) inhibit matrix metalloproteinase-2 and matrix metalloproteinase-9 activity in human prostate cancer cells via alterations in multiple cellular signalling pathways. J Cell Biochem. 2010; 111:742-54.

7. MacLean MA, Scott BE, Deziel BA, Nunnelley MC, Liberty AM, Gottschall-Pass KT, Neto CC, Hurta RA. North American cranberry (Vaccinium macrocarpon) stimulates apoptotic pathways in DU145 human prostate cancer cells in vitro. Nutr Cancer. 2011; 63:109-20.

8. Student V, Vidlar A, Bouchal J, Vrbkova J, Kolar Z, Kral M, Kosina P, Vostalova J. Cranberry intervention in patients with prostate cancer prior to radical prostatectomy. Clinical, pathological and laboratory findings. Biomed Pap Med Fac Univ Palacky Olomouc Czech Repub. 2016; 160:559-65.

9. Hamilton K, Bennett NC, Purdie G, Herst PM. Standardized cranberry capsules for radiation cystitis in prostate cancer patients in New Zealand: a randomized double blinded, placebo controlled pilot study. Support Care Cancer. 2015; 23:95-102.

10. Sun J, Hai LR. Cranberry phytochemical extracts induce cell cycle arrest and apoptosis in human MCF-7 breast cancer cells. Cancer Lett. 2006; 241:124-34.

11. Kresty LA, Howell AB, Baird M. Cranberry proanthocyanidins mediate growth arrest of lung cancer cells through modulation of gene expression and rapid induction of apoptosis. Molecules. 2011; 16:2375-90.

12. Kim KK, Singh AP, Singh RK, Demartino A, Brard L, Vorsa N, Lange TS, Moore RG. Anti-angiogenic activity of cranberry proanthocyanidins and cytotoxic properties in ovarian cancer cells. Int J Oncol. 2012; 40:227-35.

13. Wang Y, Han A, Chen E, Singh RK, Chichester CO, Moore RG, Singh AP, Vorsa N. The cranberry flavonoids PAC DP-9 and quercetin aglycone induce cytotoxicity and cell cycle arrest and increase cisplatin sensitivity in ovarian cancer cells. Int J Oncol. 2015; 46:1924-34.

14. Prasain JK, Rajbhandari R, Keeton AB, Piazza GA, Barnes S. Metabolism and growth inhibitory activity of cranberry derived flavonoids in bladder cancer cells. Food Funct. 2016; 7:4012-9.

15. Weh KM, Aiyer HS, Howell AB, Kresty LA. Cranberry proanthocyanidins modulate reactive oxygen species in Barrett's and esophageal adenocarcinoma cell lines. J Berry Res. 2016; 6:125-36.

16. Kresty LA, Weh KM, Zeyzus-Johns B, Perez LN, Howell AB. Cranberry proanthocyanidins inhibit esophageal 
adenocarcinoma in vitro and in vivo through pleiotropic cell death induction and PI3K/AKT/mTOR inactivation. Oncotarget. 2015; 6:33438-55. https://doi.org/10.18632/ oncotarget.5586.

17. Kim MJ, Ohn J, Kim JH, Kwak HK. Effects of freeze-dried cranberry powder on serum lipids and inflammatory markers in lipopolysaccharide treated rats fed an atherogenic diet. Nutr Res Pract. 2011; 5:404-11.

18. Basu A, Lyons TJ. Strawberries, blueberries, and cranberries in the metabolic syndrome: clinical perspectives. J Agric Food Chem. 2012; 60:5687-92.

19. Feliciano RP, Mecha E, Bronze MR, Rodriguez-Mateos A. Development and validation of a high-throughput micro solid-phase extraction method coupled with ultra-highperformance liquid chromatography-quadrupole timeof-flight mass spectrometry for rapid identification and quantification of phenolic metabolites in human plasma and urine. J Chromatogr A. 2016; 1464:21-31.

20. Chen PX, Dupuis JH, Marcone MF, Pauls PK, Liu R, Liu Q, Tang Y, Zhang B, Tsao R. Physicochemical Properties and in Vitro Digestibility of Cooked Regular and Nondarkening Cranberry Beans (Phaseolus vulgaris L.) and Their Effects on Bioaccessibility, Phenolic Composition, Antioxidant Activity. J Agric Food Chem. 2015; 63:10448-58.

21. Pierre JF, Heneghan AF, Feliciano RP, Shanmuganayagam D, Roenneburg DA, Krueger CG, Reed JD, Kudsk KA. Cranberry proanthocyanidins improve the gut mucous layer morphology and function in mice receiving elemental enteral nutrition. JPEN J Parenter Enteral Nutr. 2013; 37:401-9.

22. Monk JM, Lepp D, Zhang CP, Wu W, Zarepoor L, Lu JT, Pauls KP, Tsao R, Wood GA, Robinson LE, Power KA. Diets enriched with cranberry beans alter the microbiota and mitigate colitis severity and associated inflammation. J Nutr Biochem. 2016; 28:129-39.

23. Xiao X, Kim J, Sun Q, Kim D, Park CS, Lu TS, Park Y. Preventive effects of cranberry products on experimental colitis induced by dextran sulphate sodium in mice. Food Chem. 2015; 167:438-46.

24. Pierre JF, Heneghan AF, Feliciano RP, Shanmuganayagam D, Krueger CG, Reed JD, Kudsk KA. Cranberry proanthocyanidins improve intestinal sIgA during elemental enteral nutrition. JPEN J Parenter Enteral Nutr. 2014; 38:107-14.

25. Desai MS, Seekatz AM, Koropatkin NM, Kamada N, Hickey CA, Wolter M, Pudlo NA, Kitamoto S, Terrapon N, Muller A, Young VB, Henrissat B, Wilmes P, et al. A Dietary Fiber-Deprived Gut Microbiota Degrades the Colonic Mucus Barrier and Enhances Pathogen Susceptibility. Cell. 2016; 167:1339-53.e21.

26. Boateng J, Verghese M, Shackelford L, Walker LT, Khatiwada J, Ogutu S, Williams DS, Jones J, Guyton M, Asiamah D, Henderson F, Grant L, DeBruce M, et al. Selected fruits reduce azoxymethane (AOM)-induced aberrant crypt foci
(ACF) in Fisher 344 male rats. Food Chem Toxicol. 2007; 45:725-32.

27. Ferguson PJ, Kurowska EM, Freeman DJ, Chambers AF, Koropatnick J. In vivo inhibition of growth of human tumor lines by flavonoid fractions from cranberry extract. Nutr Cancer. 2006; 56:86-94.

28. Powell SM, Zilz N, Beazer-Barclay Y, Bryan TM, Hamilton SR, Thibodeau SN, Vogelstein B, Kinzler KW. APC mutations occur early during colorectal tumorigenesis. Nature. 1992; 359:235-7.

29. Jiang SS, Li JJ, Li Y, He LJ, Wang QJ, Weng DS, Pan K, Liu Q, Zhao JJ, Pan QZ, Zhang XF, Tang Y, Chen CL, et al. A novel pathogenic germline mutation in the adenomatous polyposis coli gene in a Chinese family with familial adenomatous coli. Oncotarget. 2015; 6:27267-74. https:// doi.org/10.18632/oncotarget.4776.

30. Su LK, Kinzler KW, Vogelstein B, Preisinger AC, Moser AR, Luongo C, Gould KA, Dove WF. Multiple intestinal neoplasia caused by a mutation in the murine homolog of the APC gene. Science. 1992; 256:668-70.

31. Yamada Y, Mori H. Multistep carcinogenesis of the colon in Apc(Min/+) mouse. Cancer Sci. 2007; 98:6-10.

32. Näthke IS. The adenomatous polyposis coli protein: the Achilles heel of the gut epithelium. Annu Rev Cell Dev Biol. 2004; 20:337-66.

33. Bienz M, Clevers H. Linking colorectal cancer to Wnt signaling. Cell. 2000; 103:311-20.

34. Shtutman M, Zhurinsky J, Simcha I, Albanese C, D'Amico M, Pestell R, Ben-Ze'ev A. The cyclin D1 gene is a target of the beta-catenin/LEF-1 pathway. Proc Natl Acad Sci U S A. 1999; 96:5522-7.

35. Buchanan FG, Holla V, Katkuri S, Matta P, DuBois RN. Targeting cyclooxygenase- 2 and the epidermal growth factor receptor for the prevention and treatment of intestinal cancer. Cancer Res. 2007; 67:9380-8.

36. Feng Y, Dai X, Li X, Wang H, Liu J, Zhang J, Du Y, Xia L. EGF signalling pathway regulates colon cancer stem cell proliferation and apoptosis. Cell Prolif. 2012; 45:413-9.

37. Marttinen M, Päivärinta E, Storvik M, Huikko L, LuomaHalkola H, Piironen V, Pajari AM, Mutanen M. Plant stanols induce intestinal tumor formation by up-regulating Wnt and EGFR signaling in Apc Min mice. J Nutr Biochem. 2013; 24:343-52.

38. Hung RJ, Ulrich CM, Goode EL, Brhane Y, Muir K, Chan AT, Marchand LL, Schildkraut J, Witte JS, Eeles R, Boffetta P, Spitz MR, Poirier JG, et al. Cross Cancer Genomic Investigation of Inflammation Pathway for Five Common Cancers: Lung, Ovary, Prostate, Breast, and Colorectal Cancer. J Natl Cancer Inst. 2015; 107.

39. Johansson ME, Gustafsson JK, Holmén-Larsson J, Jabbar KS, Xia L, Xu H, Ghishan FK, Carvalho FA, Gewirtz AT, 
Sjövall H, Hansson GC. Bacteria penetrate the normally impenetrable inner colon mucus layer in both murine colitis models and patients with ulcerative colitis. Gut. 2014; 63:281-91.

40. de Medina FS, Romero-Calvo I, Mascaraque C, MartínezAugustin O. Intestinal inflammation and mucosal barrier function. Inflamm Bowel Dis. 2014; 20: 2394-404.

41. Zhu C, Wu Y, Jiang Z, Zheng C, Wang L, Yang X, Ma X, Gao K, Hu Y. Dietary soy isoflavone attenuated growth performance and intestinal barrier functions in weaned piglets challenged with lipopolysaccharide. Int Immunopharmacol. 2015; 28:288-94.

42. Puppa MJ, White JP, Sato S, Cairns M, Baynes JW, Carson JA. Gut barrier dysfunction in the Apc(Min/+) mouse model of colon cancer cachexia. Biochim Biophys Acta. 2011; 1812:1601-6.

43. Montoya CA, Rutherfurd SM, Moughan PJ. Kiwifruit fibre level influences the predicted production and absorption of SCFA in the hindgut of growing pigs using a combined in vivo-in vitro digestion methodology. Br J Nutr. 2016; 115:1317-24.

44. Anhê FF, Roy D, Pilon G, Dudonné S, Matamoros S, Varin TV, Garofalo C, Moine Q, Desjardins Y, Levy E, Marette A. A polyphenol-rich cranberry extract protects from diet-induced obesity, insulin resistance and intestinal inflammation in association with increased Akkermansia spp. population in the gut microbiota of mice. Gut. 2015; 64:872-83.

45. O'Keefe SJ. Diet, microorganisms and their metabolites, and colon cancer. Nat Rev Gastroenterol Hepatol. 2016; 13:691-706.

46. Blumberg JB, Basu A, Krueger CG, Lila MA, Neto CC, Novotny JA, Reed JD, Rodriguez-Mateos A, Toner CD. Impact of Cranberries on Gut Microbiota and Cardiometabolic Health: Proceedings of the Cranberry Health Research Conference 2015. Adv Nutr. 2016; 7: 759S-70S.

47. Krueger CG, Reed JD, Feliciano RP, Howell AB. Quantifying and characterizing proanthocyanidins in cranberries in relation to urinary tract health. Anal Bioanal Chem. 2013; 405:4385-95.

48. Xiao X, Kim J, Sun Q, Kim D, Park CS, Lu TS, Park Y. Preventive effects of cranberry products on experimental colitis induced by dextran sulphate sodium in mice. Food Chem. 2015; 167:438-46.

49. Rodríguez-Pérez C, Quirantes-Piné R, Uberos J, JiménezSánchez C, Peña A, Segura-Carretero A. Antibacterial activity of isolated phenolic compounds from cranberry (Vaccinium macrocarpon) against Escherichia coli. Food Funct. 2016; 7:1564-73.

50. Abeywickrama G, Debnath SC, Ambigaipalan P, Shahidi F. Phenolics of Selected Cranberry Genotypes (Vaccinium macrocarpon Ait.) and Their Antioxidant Efficacy. J Agric Food Chem. 2016; 64:9342-51.

51. Viskelis P, Rubinskiene M, Jasutiene I, Sarkinas A, Daubaras R, Cesoniene L. Anthocyanins, antioxidative, and antimicrobial properties of American cranberry (Vaccinium macrocarpon Ait.) and their press cakes. J Food Sci. 2009; 74: C157-61.

52. Zhang Y, Sun Y, Xi W, Shen Y, Qiao L, Zhong L, Ye X, Zhou Z. Phenolic compositions and antioxidant capacities of Chinese wild mandarin (Citrus reticulata Blanco) fruits. Food Chem. 2014; 145:674-80.

53. Feliciano RP, Meudt JJ, Shanmuganayagam D, Krueger CG, Reed JD. Ratio of "A-type" to "B-type" proanthocyanidin interflavan bonds affects extra-intestinal pathogenic Escherichia coli invasion of gut epithelial cells. J Agric Food Chem. 2014; 62:3919-25.

54. Olmedilla-Alonso B, Pedrosa MM, Cuadrado C, Brito M, Asensio-S-Manzanera C, Asensio-Vegas C. Composition of two Spanish common dry beans (Phaseolus vulgaris), 'Almonga' and 'Curruquilla', and their postprandial effect in type 2 diabetics. J Sci Food Agric. 2013; 93:1076-82.

55. Thompson SV, Winham DM, Hutchins AM. Bean and rice meals reduce postprandial glycemic response in adults with type 2 diabetes: a cross-over study. Nutr J. 2012; 11: 23.

56. Zhang C, Monk JM, Lu JT, Zarepoor L, Wu W, Liu R, Pauls KP, Wood GA, Robinson L, Tsao R, Power KA. Cooked navy and black bean diets improve biomarkers of colon health and reduce inflammation during colitis. Br J Nutr. 2014; 111:1549-63.

57. Saleh $\mathrm{M}$, Trinchieri G. Innate immune mechanisms of colitis and colitis-associated colorectal cancer. Nat Rev Immunol. 2011; 11:9-20.

58. Lasry A, Zinger A, Ben-Neriah Y. Inflammatory networks underlying colorectal cancer. Nat Immunol. 2016; 17:230-40.

59. West NR, McCuaig S, Franchini F, Powrie F. Emerging cytokine networks in colorectal cancer. Nat Rev Immunol. 2015; 15:615-29.

60. Brown PN, Turi CE, Shipley PR, Murch SJ. Comparisons of large (Vaccinium macrocarpon Ait.) and small (Vaccinium oxycoccos L., Vaccinium vitis-idaea L.) cranberry in British Columbia by phytochemical determination, antioxidant potential, and metabolomic profiling with chemometric analysis. Planta Med. 2012; 78:630-40.

61. Carpenter JL, Caruso FL, Tata A, Vorsa N, Neto CC. Variation in proanthocyanidin content and composition among commonly grown North American cranberry cultivars (Vaccinium macrocarpon). J Sci Food Agric. 2014; 94:2738-45.

62. Johnson MH, de Mejia EG, Fan J, Lila MA, Yousef GG. Anthocyanins and proanthocyanidins from blueberryblackberry fermented beverages inhibit markers of 
inflammation in macrophages and carbohydrate-utilizing enzymes in vitro. Mol Nutr Food Res. 2013; 57:1182-97.

63. Romier B, Schneider YJ, Larondelle Y, During A. Dietary polyphenols can modulate the intestinal inflammatory response. Nutr Rev. 2009; 67:363-78.

64. Ruiz PA, Braune A, Hölzlwimmer G, Quintanilla-Fend L, Haller D. Quercetin inhibits TNF-induced NF-kappaB transcription factor recruitment to proinflammatory gene promoters in murine intestinal epithelial cells. J Nutr. 2007; 137:1208-15.

65. Luissint AC, Parkos CA, Nusrat A. Inflammation and the Intestinal Barrier: Leukocyte-Epithelial Cell Interactions, Cell Junction Remodeling, Mucosal Repair. Gastroenterology. 2016; 151:616-32.

66. Li Y, Kundu P, Seow SW, de Matos CT, Aronsson L, Chin KC, Kärre K, Pettersson S, Greicius G. Gut microbiota accelerate tumor growth via c-jun and STAT3 phosphorylation in APCMin/+ mice. Carcinogenesis. 2012; 33:1231-8.

67. Encarnação JC, Abrantes AM, Pires AS, Botelho MF. Revisit dietary fiber on colorectal cancer: butyrate and its role on prevention and treatment. Cancer Metastasis Rev. 2015; 34:465-78.

68. Vong MH, Stewart ML. In vitro bacterial fermentation of tropical fruit fibres. Benef Microbes. 2013; 4:291-5.

69. Hamer HM, Jonkers D, Venema K, Vanhoutvin S, Troost FJ, Brummer RJ. Review article: the role of butyrate on colonic function. Aliment Pharmacol Ther. 2008; 27:104-19.

70. Leonel AJ, Alvarez-Leite JI. Butyrate: implications for intestinal function. Curr Opin Clin Nutr Metab Care. 2012; 15:474-9.

71. Segain JP, Raingeard de la Blétière D, Bourreille A, Leray V, Gervois N, Rosales C, Ferrier L, Bonnet C, Blottière HM, Galmiche JP. Butyrate inhibits inflammatory responses through NFkappaB inhibition: implications for Crohn's disease. Gut. 2000; 47:397-403.
72. Nagy-Szakal D, Hollister EB, Luna RA, Szigeti R, Tatevian $\mathrm{N}$, Smith CW, Versalovic J, Kellermayer R. Cellulose supplementation early in life ameliorates colitis in adult mice. PLoS One. 2013; 8: e56685.

73. Langlands SJ, Hopkins MJ, Coleman N, Cummings JH. Prebiotic carbohydrates modify the mucosa associated microflora of the human large bowel. Gut. 2004; 53:1610-6.

74. Jakobsdottir G, Xu J, Molin G, Ahrné S, Nyman M. Highfat diet reduces the formation of butyrate, but increases succinate, inflammation, liver fat and cholesterol in rats, while dietary fibre counteracts these effects. PLoS One. 2013; 8: e80476.

75. Bränning C, Håkansson A, Ahrné S, Jeppsson B, Molin G, Nyman M. Blueberry husks and multi-strain probiotics affect colonic fermentation in rats. Br J Nutr. 2009; 101:859-70.

76. Seeram NP, Adams LS, Hardy ML, Heber D. Total cranberry extract versus its phytochemical constituents: antiproliferative and synergistic effects against human tumor cell lines. J Agric Food Chem. 2004; 52:2512-7.

77. Pearson G, Robinson F, Beers GT, Xu BE, Karandikar M, Berman K, Cobb MH. Mitogen-activated protein (MAP) kinase pathways: regulation and physiological functions. Endocr Rev. 2001; 22:153-83.

78. Dietrich WF, Lander ES, Smith JS, Moser AR, Gould KA, Luongo C, Borenstein N, Dove W. Genetic identification of Mom-1, a major modifier locus affecting Min-induced intestinal neoplasia in the mouse. Cell. 1993; 75:631-9.

79. Cao H, Luo S, Xu M, Zhang Y, Song S, Wang S, Kong X, He N, Cao X, Yan F, Wang B. The secondary bile acid, deoxycholate accelerates intestinal adenomaadenocarcinoma sequence in Apc ( $\mathrm{min} /+)$ mice through enhancing Wnt signaling. Fam Cancer. 2014; 13:563-71. 